\title{
Media Pembelajaran Online Berbasis Geogebra sebagai Upaya Meningkatkan Pemahaman Konsep Matematika
}

\author{
I Putu Pasek Suryawan,", Dodi Permana ${ }^{2}$ \\ 1,2 Universitas Pendidikan Ganesha \\ *pasek.suryawan@yahoo.co.id
}

\begin{tabular}{|l|l|l|} 
Received : $11-2020$ & Revised: $12-4-2020$ & Accepted: $12-4-2020$
\end{tabular}

\begin{abstract}
ABSTRAK
Penelitian ini merupakan penelitian pengembangan yang bertujuan untuk memperoleh kevalidan, kepraktisan, dan keefektivan media pembelajaran pada materi bangun ruang sisi lengkung sebagai upaya meningkatkan pemahaman konsep siswa. Media pembelajaran yang dikembangkan menggunakan Kurikulum 2013. Model pengembangan yang digunakan adalah Model 4D (define, design, develop, dan disseminate), namun dalam penelitian ini hanya sampai tahap develop. Media pembelajaran ini dibuat menggunakan software Geogebra dan dioperasikan dengan bantuan Schoology. Hasil penelitian menunjukkan bahwa validitas media pembelajaran yang dikembangkan berada pada kriteria sangat valid, dengan rata-rata skor dari ahli media sebesar 4,2 dan ahli materi sebesar 4,5. Kepraktisan media pembelajaran yang diperoleh melalui pengisian angket respon setelah pembelajaran berada pada kriteria sangat praktis, dengan rata-rata skor dari respon siswa sebesar 4,44 dan respon dari guru sebesar 4,5. Sedangkan, hasil penelitian mengenai efektivitas media pembelajaran yang diperoleh melalui tes pemahaman konsep matematika siswa menunjukkan bahwa 93,33\% siswa berada pada kategori tuntas setelah mengikuti pembelajaran menggunakan media pembelajaran yang dikembangkan.
\end{abstract}

Kata Kunci : Media Pembelajaran, Model 4D, Bangun Ruang Sisi Lengkung, Pemahaman Konsep

\begin{abstract}
The present study aims at developing a valid, practice and effective learning media for curved solids topic that will support the students' conceptual understanding. To achieve the goal, developmental design with 4D Model was employed. Generally, there are four steps in 4D Model, i.e. Define, Design, Develop and Disseminate. However, due to limitations, this study solely applying the first three steps. The learning media was developed using GeoGebra software and operated using Schoology. The learning principles applied in the media was adjusted with the National Curriculum of 2013 by emphasizing the students' participation. The validity data were gathered from experts' judgement while the practicability were observed from teacher's and students' response after using media and the effectivity data were gathered from students' written work in solving conceptual understanding related test. The results showed that the validity of learning media is in very valid category, with average score from media experts was 4.2 and average score from content experts was 4.5 out of 5. The practicability of the learning media was very good, since the students' average score was 4.44 and teacher's score was 4.5 out of 5 . Furthermore, the effectivity of the learning media showed from $93.33 \%$ students who used the media were passing the minimum requirement score in the test.
\end{abstract}

Keywords: Learning Media, 4D Model, Curved Solids, Conceptual Understanding 


\section{PENDAHULUAN}

Matematika merupakan ilmu dasar yang penerapannya dibutuhkan oleh ilmu pengetahuan dan teknologi (Maskur et al., 2020; Parwati, Suryawan, \& Apsari, 2018). Ironisnya matematika dikalangan peserta didik merupakan mata pelajaran yang kurang disukai, sehingga penguasaan siswa terhadap konsep matematika kurang optimal, khususnya pada beberapa topik yang dianggap sulit untuk dibayangkan (Suryawan, 2019). Sebenarnya banyak upaya sudah dilakukan untuk mengatasi masalah ini, namun belum terlaksana secara optimal pada topik tertentu, misalnya pada topik bangun ruang sisi lengkung. Siswa masih mengalami kesulitan dalam membayangkan objek tiga dimensi, karena dalam pembelajaran bangun ruang sisi lengkung ini siswa hanya dihadapakan pada gambar-gambar dua dimensi yang ada dibuku atau dituliskan di papan. Selain itu, siswa hanya menghafal rumus tanpa memahami konsep, dimana materi ini semestinya memerlukan bantuan visualisasi yang tepat (Septian \& Komala, 2019). Merujuk pada hasil identifikasi masalah tersebut, sesungguhnya masalah yang ditemukan dapat diatasi dengan memberikan kesempatan kepada siswa untuk mengalami sendiri penemuan konsep melalui simulai media pembelajaran pada topik bangun ruang sisi lengkung tersebut (Widodo, 2018).

Media pembelajaran matematika mampu membantu menyajikan konsep-konsep yang abstrak menjadi sederhana dengan mengintegrasikan gambar, video, suara, dan animasi (Musfiqon, 2012). Dalam perkembangannya, sudah banyak terdapat software yang dapat dimanfaatkan untuk membuat suatu media pembelajaran matematika, misalnya software geogebra. Pemanfaatan software geogebra relevan digunakan dalam pembelajaran pada Kurikulum 2013 yang menitik beratkan pada pelaksanaan pembelajaran dengan pendekatan saintifik, dimana terdiri dari 5M yaitu: (1) Mengamati, (2) Menanya, (3) Mengumpulkan Informasi, (4) Mengasosiasi, (5) Mengomunikasikan. Media pembelajaran berbasis geogebra dengan pendekatan 5M ini dapat dimanfaatkan siswa secara mandiri dalam belajar dengan dilengkapi fasilitas eksplorasi konsep untuk siswa (Suryawan, 2019).

Media pembelajaran berbasis geogebra dengan pendekatan saintifik yang sudah pernah dikembangkan sebelumnya, yaitu penelitian yang dilakukan oleh Wirapathi, dkk. (2018) yang hasilnya menyatakan bahwa media pembelajaran geometri transformasi berbasis geogebra dengan pendekatan 5M telah memenuhi kriteria valid, praktis, dan efektif untuk meningkatkan pemahaman konsep siswa pada materi geometri. Namun, media pembelajaran yang dikembangkan tersebut hanya dimanfaatkan sebagai pelengkap 
pembelajaran dan belum bisa berdiri sendiri sebagai media pembelajaran yang utuh. Selain itu, penulis sendiri Suryawan, (2019), juga sudah berupaya menyempurnakan penelitian Wirapathi, dkk., (2018) dengan melakukan penelitian pengembangan media pembelajaran matematika berbasis lectora inspire dengan pendekatan saintifik yang didalamnya juga memanfaatakn software geogebra. Hasil penelitian tersebut telah menghasilkan media pembelajaran matematika yang tidak hanya sebagai pelengkap pembelajaran, tetapi mampu juga berdiri sendiri dalam memfasilitasi siswa menemukan konsep dengan fasilitas eksplorasinya. Namun, dalam perkembangannya media pembelajaran yang selama ini kembangkan masih berbentuk media offline. Dalam penggunaanya, media offline ini masih memiliki kekurangan, yang salah satunya adalah siswa tidak bisa leluasa menggunakan media di luar sekolah (Rusman, 2012). Dengan berkembangnya penggunaan internet sekarang ini, pemanfaatkan internet dalam pembelajaran yang dikenal dengan sebutan $e$ learning dapat menghasilkan media online yang dikemas dengan portal e-learning (Effendi, 2005).

Penelitian Sudiarta (2018) yang berjudul "Investigasi pada Diskusi Online Matematika Siswa: Sebuah Studi Kasus di Kelas VIII SMPN 1 Denpasar", menyatakan bahwa diskusi online mampu menciptakan kemampuan matematika yang sangat signifikan (pemahaman konseptual, kelancaran prosedural, kompetensi strategis, penalaran adaptif, disposisi produktif) dan keterampilan komunikasi (klarifikasi, saran). Lebih lanjut, (Sukawijaya \& Sudiarta, 2018) menyatakan bahwa dalam penggunaan e-learning ini dapat memudahkan pengguna untuk mengakses pembelajaran dimanapun dan kapanpun, serta elearning juga dapat mengurangi biaya dalam proses pembelajaran. Schoology merupakan salah satu portal e-learning yang terbaik pemanfaatannya, karena konten-konten yang tidak dimiliki portal e-learning lainnya dimiliki oleh schoology, serta dapat diakses dengan gratis (Aminoto \& Pathoni, 2014).

Berdasarkan uraian tersebut di atas, untuk dapat menumbuhkan aktivitas pembelajaran matematika siswa di dalam maupun luar kelas, guru perlu menyediakan media yang mampu memfasilitasi siswa dalam aktivasi sumber belajar yang relevan sesuai dengan tuntutan pendidikan di era revolusi industri 4.0 dan menyongsong era 5.0 society. Dengan demikian, penelitian ini bertujuan untuk mengembangkan media pembelajaran online berbasis geogebra yang valid, praktis, dan efektif untuk meningkatakan kemampuan pemahaman konsep matematika siswa pada topik bangun ruang sisi lengkung. 


\section{METODE PENELITIAN}

Penelitian ini dilaksanakan dengan pendekatan penelitian dan pengembangan (research and development). Jenis penelitian ini merupakan suatu metode yang digunakan guna menghasilkan suatu produk tertentu dan menguji keefektifan dari produk tertentu (Sugiyono, 2011). Model pengembangan yang digunakan dalam penelitian ini mengikuti tahapan-tahapan dari model pengembangan Four-D (4-D) yang dikembangkan oleh Thiagarajan, Doroty S. Semmel, dan Melvyn I. Semmel. Model pengembangan model 4-D terdiri atas empat tahapan utama (Thiagarajan, 2018), yakni pendefinisian (define), perancangan (design), pengembangan (development), dan penyebaran (disseminate), namun pada penelitian ini hanya sampai pada tahap pengembangan saja.

Instrumen yang digunakan dalam penelitian ini, yaitu: (1) angket validasi ahli media, (2) angket validasi ahli isi materi, (3) angket respon siswa, dan (4) angket respon guru, dan (5) tes pemahaman konsep matematika siswa. Sampel yang digunakan dalam uji coba terbatas ini adalah 10-20 siswa yang mencerminkan karakteristik populasi (Tegeh \& Kirna, 2010). Teknik analisis data yang digunakan dalam penelitian ini adalah teknik analisis data kualitatif dan deskriptif kuantitatif, yang digunakan untuk mengetahui validitas, kepraktisan, dan keefektifan media pembelajaran yang dikembangkan.

\section{HASIL DAN PEMBAHASAN}

Dengan merujuk pada Model 4-D, hasil penelitian pengembangan ini diuraikan sesuai dengan tahapan-tahapan dari model pengembangan 4-D. Pada tahap define, dilakukan kegiatan analisis awal dan analisis kurikulum terkait topik bangun ruang sisi lengkung, perangkat pendukung pembelajaran yang ada, media pembelajaran yang ada, serta melakukan kajian teori dan kajian penelitian relevan, sampai didapatkan konsep dasar untuk menyelesaikan permasalahan yang dihadapi. Setelah melakukan analisis awal dan analisis kurikulum, selanjutnya masuk ke tahap design. Pada tahap design ini, dilakukan perancangan media pembelajaran yang akan dikembangkan melalui hasil dari analisis sebelumnya, sehingga didapat rancang bangun dari media bangun ruang sisi lengkung untuk siswa SMP kelas IX pada Kurikulum 2013. Terdapat beberapa komponen dalam rancang bangun media ini, yaitu: 1) KD dan Indikator, 2) Video Apersepsi, 3) Profil, 4) Tujuan Pembelajaran, 5) Materi Volume, 6) Materi Luas Permukaan, 7) Contoh Soal, dan 8) Latihan Soal. Berikut diuraikan hal-hal yang termuat dalam Media Pembelajaran Bangun Ruang Sisi Lengkung secara singkat. 
Saat media pembelajaran ini dijalankan akan muncul seperti pada Gambar 1. Untuk memulai pembelajaran siswa dapat memilih MULAI PEMBELAJARAN. Sedangkan, untuk melihat identitas pengembang siswa dapat memilih menu PROFIL PENGEMBANG.

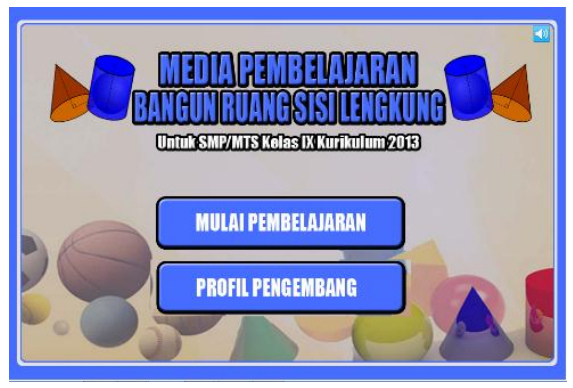

Gambar 1. Tampilan Awal Media Pembelajaran

Setelah siswa memilih MULAI PEMBELAJARAN akan muncul tampilan seperti Gambar 2. Dimana siswa akan diajak untuk melihat video kontekstual dari pembelajaran.

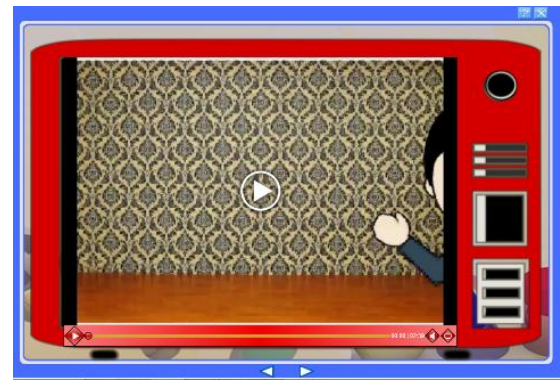

Gambar 2. Tampilan Video Apersepsi

Pada menu MATERI terdapat tiga halaman, dan saat siswa memilih menu ini siswa akan diperlihatkan video permasalahan, misalnya mengenai topik Volume. Setelah itu, siswa akan diajak ke halaman berikutnya yaitu pengantar mengenai bangun ruang yang membantu siswa untuk memahami konsep volume, dan halaman selanjutnya yaitu media eksplorasi, dimana siswa nantinya dapat menentukan dan menemukan rumus dari volume bangun ruang sisi lengkung. Untuk tampilan halaman Volume dapat dilihat seperti pada Gambar 3 ini.

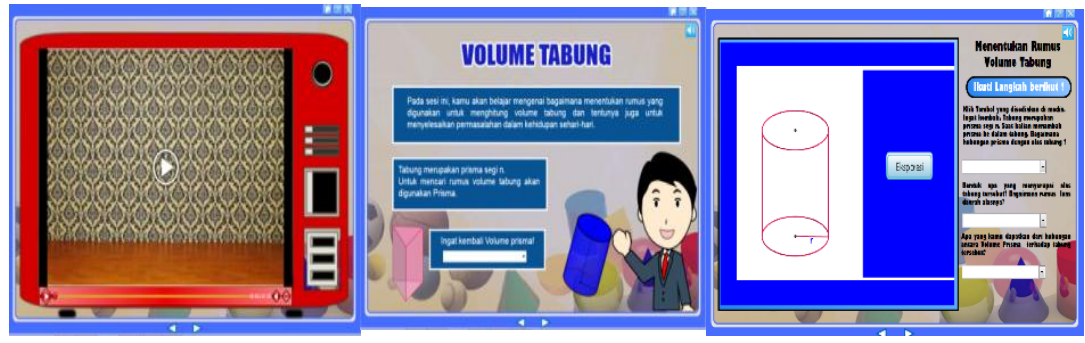

Gambar 3. Tampilan Konten Halaman Volume Tabung

Setelah Siswa mempelajarai semua materi pada halaman sebelumnya, siswa akan diberikan 10 latihan soal mengenai volume dan luas permukaan seperti Gambar 4. 


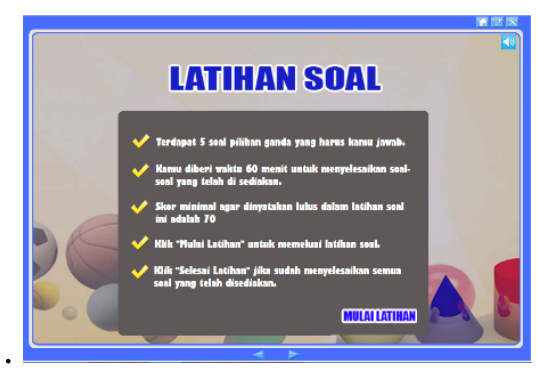

Gambar 4. Tampilan Latihan Soal

Media pembelajaran tersebut dikembangkan berbasis software geogebra dengan merujuk pada pendekatan 5M yang merupakan roh dari Kurikulum 2013. Setelah rancang bangun media ini selesai diimplementasikan menjadi suatu media, selanjutnya media ini dintegrasikan secara online menggunakan bantuan web schoology, dan siap untuk dievaluasi kelayakannya baik aspek validitas, kepraktisan, maupun keefektivannya secara berturut-turut.

Nieveen (1999) menyatakan bahwa kualitas suatu produk pembelajaran dikatakan berkualitas jika produk tersebut memenuhi 3 aspek, yaitu: (1) validitas (validity); (2) kepraktisan (practically); dan (3) efektivitas (effectiveness). Untuk melihat aspek validitas media pembelajaran melibatkan satu orang ahli media dan dua orang ahli isi materi, yang hasilnya seperti pada Tabel 1 berikut.

Tabel 1. Rangkuman Hasil Uji Validitas Media Pembelajaran

\begin{tabular}{ll}
\hline Skor Total Ahli Media & 34 \\
\hline Rata-rata Skor Ahli Media & 4,2 \\
\hline Kriteria & Sangat Valid \\
\hline Skor Total Ahli Materi 1 & 40 \\
\hline Skor Total Ahli Materi 2 & 41 \\
\hline Rata-rata Skor Ahli Materi & 4,5 \\
\hline Kriteria & Sangat Valid \\
\hline
\end{tabular}

Tabel 1 di atas menunjukkan bahwa media pembelajaran ini berada pada kategori sangat valid, dan tentunya dengan beberapa revisi untuk penyempurnaan media pembelajaran yang dikembangkan. Setelah direvisi, media pembelajaran yang dikembangkan ini dilanjutkan dengan uji coba terbatas pada kelompok kecil untuk melihat kepraktisan dan efektivitasnya.

Dalam menilai kepraktisan media pembelajaran yang dikembangkan ini dilihat dari skor angket respon siswa dan skor angket respon guru, yang dapatkan setelah ujicoba terbatas. Adapun rangkuman hasil respon guru dan siswa disajikan seperti Tabel 2 berikut. 
Tabel 2. Rangkuman Hasil Respon Guru dan Siswa terhadap Media Pembelajaran

\begin{tabular}{ll}
\hline Rata-rata Skor Respon Guru & 4,54 \\
\hline Rata-rata Skor Respon Siswa & 4,44 \\
\hline Kriteria & Sangat Tinggi \\
\hline
\end{tabular}

Tabel 2 di atas menunjukkan bahwa siswa dan guru praktis menggunakan atau menerapkan media pembelajaran yang dikembangkan. Selanjutnya, untuk menilai keefektivan media pembelajaran yang dikembangkan dalam penelitan ini dilihat berdasarkan persentase ketuntasan belajar siswa peserta uji coba terbatas, yang hasilnya seperti Tabel 3 berikut.

Tabel 3. Hasil Tes Pemahaman Konsep Materi Bangun Ruang Sisi Lengkung

\begin{tabular}{lll}
\hline No & Variasi & Skor \\
\hline 1. & Nilai Tertinggi & 100 \\
\hline 2. & Nilai Terendah & 55,6 \\
\hline 3. & Rata-rata & 75 \\
\hline 4. & Banyak siswa yang tuntas & 14 \\
\hline 5. & Banyak siswa yang belum tuntas & 1 \\
\hline 6. & Persentase ketuntasan & $\mathbf{9 3 , 3 3 \%}$ \\
\hline
\end{tabular}

Tabel 3 di atas menunjukkan bahwa persentase ketuntasan belajar siswa yang mengikuti uji coba terbatas dengan menggunakan media pembelajaran yang dikembangkan sangat tinggi, yaitu sebesar 93,33\%. Oleh karena itu, berdasarkan hasil uji validasi ahli dan uji coba terbatas tersebut dapat disimpulkan bahwa media pembelajaran online berbasis geogebra pada topik bangun ruang sisi lengkung telah memenuhi aspek validitas, kepraktisan, dan keefektivan yang telah ditentukan.

Keberhasilan memperoleh media pembelajaran online berbasis geogebra yang valid, praktis, dan efektif ini disebabkan karena siswa lebih senang belajar dan mencari sumber belajar melalui internet. Siswa merasa bahwa belajar dan mencari sumber belajar di internet lebih mudah dan menyenangkan di era sekarang. Melalui implementasi TIK (dalam hal ini pemanfaatan software geogebra) pada media pembelajaran online (pemanfaatan web schoology), proses pembelajaran matematika lebih berpusat kepada siswa (student centered) sehingga hasil belajar meningkat (Rahman, dkk., 2014). Apalagi dalam mengembangkan media ini mengacu pada pendekatan saintifik, maka media yang dihasilkan memang dirancang secara khusus untuk merangsang pikiran, perasaan, perhatian, dan kemauan peserta didik sehingga terjadinya proses pembelajaran. Selain itu, media pembelajaran yang dikembangkan ini memuat informasi yang dapat berupa pengetahuan maupun menjadi sarana bagi siswa untuk melakukan aktivitas belajar seperti: 
membaca, mengamati, mencoba, mengerjakan soal, menjawab pertanyaan, dan lain-lain (Sahid, 2010). Hal tersebut dipertegas bahwa fungsi pemanfaatan media pembelajaran sangat penting karena membicarakan kaitan antara peserta didik dengan bahan belajar atau sistem pembelajaran (Septian, 2017; Warsita, 2008). Dengan kata lain, media pembelajaran online berbasis geogebra ini dapat dijadikan salah satu sumber belajar yang tepat dalam rangka aktivasi sumber belajar yang meruapakan salah satu tuntutan pembelajaran di era revolusi industri 4.0.

Keefektivan media pembelajaran yang dikembangkan ini mampu meningkatkan pemahaman konsep matematika siswa karena media pembelajaran ini sudah mengacu pada indikator pemahaman konsep matematika berdasarkan NCTM (2000), yaitu: (1) mampu menyatakan konsep dengan kata-kata sendiri, dimana indikator pertama ini terakomodasi dalam media pembelajaran tepatnya pada akhir dari setiap video pembelajaran kontekstual yang disajikan; (2) memberikan contoh dan bukan contoh dari konsep, dimana indikator kedua juga sudah terakomodasi dalam dalam video pembelajaran dan media eksplorasi yang dibuat dengan geogebra; dan (3) menggunakan konsep dengan benar dalam berbagai situasi, begitu juga dengan indikator ketiga sudah terakomodasi dalam media pembalajaran tepatnya pada media eksplorasi geogebra dan menu evaluasi yang melatih siswa dalam penemuan konsep dan pengaplikasian konsep tersebut. Dengan demikian, tepat dikatakan bahwa media pembelajaran ini layak untuk dimanfaatkan baik sebagai suplemen atau berdiri sendiri untuk memfasilitasi siswa dalam penemuan konsep di dalam maupun di luar kelas.

Hasil penelitian ini sejalan dengan hasil penelitian Permatasari (2016), yang berjudul "Pengembangan Media Pembelajaran Matematika Interaktif Schoology Berbantuan Software Geogebra Materi Transformasi Geometri Kelas XI", dimana samasama mengembangkan media pembelajaran dengan alat bantu geogebra sebagai media eksplorasi dan efektif meningkatkan pemahaman konsep matematika siswa pada topik transformasi geometri. Lebih lanjut, hasil penelitian ini juga mampu menjawab kekurangan dari hasil penelitian yang dilakukan peneliti sendiri sebelumnya Suryawan (2019), dimana dengan penyajian online pada penelitian ini memberikan keleluasan kepada siswa untuk belajar dimana pun dan kapan pun dengan tetap mengikuti pendekatan saintifik pada penerapan Kurikulum 2013.

Produk berupa media pembelajaran yang dihasilkan dari penelitian ini tentu memiliki kelebihan dan kekurangan. Kelebihannya, yaitu: (1) media pembelajaran dapat membantu siswa untuk belajar mandiri ataupun membantu guru dalam proses 
pembelajaran di kelas; (2) media pembelajaran ini mudah diakses melalui online; (3) terdapat media eksplorasi yang dapat membantu siswa mempelajari suatu konsep; dan (4) disesuaikan dengan Kurikulum 2013. Sedangkan kekurangannya, yaitu: 1) tidak terdapat materi prasyarat pada media ini, sehingga siswa wajib memahami materi prasyarat agar dapat memudahkan dalam menggunakan media pembelajaran ini; 2) materi yang diambil hanya fokus pada penemuan rumus volume dan luas permukaan bangun ruang sisi lengkung saja; dan 3) media yang dikembangkan hanya sampai mengembangkan produk dalam skala yang sempit.

\section{KESIMPULAN}

Berdasarkan hasil dan pembahasan penelitian, dapat disimpulkan bahwa media pembelajaran online berbasis geogebra pada topik bangun ruang sisi lengkung telah memenuhi kriteria valid, praktis, dan efektif mampu meningkatkan kemampuan pemahaman konsep matematika siswa SMP kelas IX. Selain itu, media ini juga sesuai dengan pendekatan pembelajaran saintifik yang merupakan roh dari Kurikulum 2013, serta dapat dijadikan sebagai salah satu sumber relevan yang mampu memfasilitasi siswa dalam aktivasi sumber belajar matematika sesuai dengan tuntutan pembelajaran di era revolusi industri 4.0.

\section{REFERENSI}

Aminoto, T., \& Pathoni, H. (2014). Penerapan Media E-Learning Berbasis Schoology untuk Meningkatkan Aktivitas dan Hasil Belajar Siswa. Jurnal Pendidikan Fisika, 8, 13-29.

Effendi, E. (2005). E-Learning Konsep dan Aplikasi. Yogyakarta: ANDI.

Maskur, R., Sumarno, Rahmawati, Y., Pradana, K., Syazali, M., Septian, A., \& Palupi, E. K. (2020). The effectiveness of problem based learning and aptitude treatment interaction in improving mathematical creative thinking skills on curriculum 2013. European Journal of Educational Research, 9(1), 375-383. https://doi.org/10.12973/eu-jer.9.1.375

Musfiqon, H. (2012). Pengembangan Media Pembelajaran. Jakarta: Prestasi Pustakaraya.

NCTM. (2000). Mathematics Assesment a Practical Handbook for Grades 6-8. United States of America: NCTM.

Nieveen, N. J. (1999). Design Approaches and Toos in Education and Training. Dordrecht: Kluwer Academic Publishers.

Parwati, N. N., Suryawan, I. P. P., \& Apsari, R. A. (2018). Belajar dan Pembelajaran (1st ed.). Singaraja: PT RAJAGRAFINDO PERSADA.

Permatasari, P. A., Dafik, \& Fatahilah, A. (2016). Pengembangan Media Pembelajaran Matematika Interaktif Schoology Berbantuan Software Geogebra Materi Transformasi Geometri Kelas Xi. Kadikma, 7(1), 66-75.

Rahman, S., Munawar, W., \& Berman, E. T. (2014). Pemanfaatan Media Pembelajaran Berbasis Website Pada Proses Pembelajaran Produktif Di Smk. Journal of 
$\begin{array}{llll}\text { Mechanical Engineering } & \text { Education, } & 1(1), & \end{array}$ https://doi.org/10.17509/jmee.v1i1.3746

Rusman. (2012). Model-model Pembelajaran Mengembangkan Profesionalisme Guru. Jakarta: Raja Grafindo Perkasa.

Sahid. (2010). Pengembangan Media Pembelajaran Berbasis ICT. Pendidikan Matematika FMIPA UNY, 1-16.

Septian, A. (2017). Penerapan Geogebra untuk Meningkatkan Kemampuan Pemecahan Masalah Matematis Mahasiswa Program Studi Pendidikan Matematika Universitas Suryakancana. PRISMA, 6(2). https://doi.org/10.35194/jp.v6i2.212

Septian, A., \& Komala, E. (2019). Kemampuan Koneksi Matematik dan Motivasi Belajar Siswa dengan Menggunakan Model Problem-Based Learning (PBL) Berbantuan Geogebra di SMP. PRISMA, 8(1), 1-13. https://doi.org/10.35194/jp.v8i1.438

Sudiarta, I. G. P., Sukajaya, I. N., \& Suharta, I. G. P. (2018). Investigation on students' mathematical online discussion: A case study in grade 8 SMPN 1 Denpasar. Journal of Physics: Conference Series, 1040(1). https://doi.org/10.1088/17426596/1040/1/012031

Sugiyono. (2011). Metode Penelitian Kuantitatif Kualitatif dan R\&D. Bandung: Alfabeta.

Sukawijaya, I. M. G., \& Sudiarta, I. G. P. (2018). Developing blended learning environment to improve learning performance and self-reliance for junior high school students. Journal of Physics: Conference Series, 1040(1). https://doi.org/10.1088/1742-6596/1040/1/012030

Suryawan, I. P. P. (2019). Rancang Bangun Dan Implementasi Media Pembelajaran Matematika Berbasis Lectorainspire Dengan Pendekatan Saintifik. Jurnal Santiaji Pendidikan (JSP), 9(2), 177-188. https://doi.org/10.36733/jsp.v9i2.399

Tegeh, I. M., \& Kirna, I. M. (2010). Metode Penelitian Pengembangan Pendidikan. Singaraja: Undiksha.

Thiagarajan, S. (2018). Instructional Development for Training Teachers of Exceptional Children a Sourcebook.

Warsita, B. (2008). Teknologi Pembelajaran: Teori dan Aplikasinya. Jakarta: Rineka Cipta.

Widodo, S. A. (2018). Selection of Learning Media Mathematics for Junior School Students. Turkish Online Journal of Educational Technology - TOJET, 17(1), 154160.

Wirapathi, A., Candiasa, M., \& Suryawan, P. (2018). The Development of Transformation Geometry Learning Medium with Scientific Approach As Effort to Improve the Understanding Concept Skill. Journal of Education Technology, 2(2), 76. https://doi.org/10.23887/jet.v2i2.16185 